\title{
Nogen må jo tage et ansvar \\ - om samskabelse og samfundsansvar
}

\author{
Af Katrin Hjort *)
}

\author{
"Vi holder borgerne vak - fordi de gerne vil klare sig selv". \\ Første ledetråd i Århus Kommunes strategi for fremtidens sundhed og \\ omsorg: "Kærlig Kommune". www.aarhus.dk 16.11.2016
}

\section{Resumé}

Begrebet samskabelse har karakter af det store dyr i åbenbaringen, når vi i Danmark i dag diskuterer velfærd i form af sundhed, uddannelse og social sikkerhed. Men hvilke betydninger kan begrebet have? Har vi at gøre med, hvad Ernesto Laclau (1996) kalder en "flydende betegner" - et begreb, hvis referencer til faktiske fænomener og processer endnu ikke er endeligt fastlagt, og som derfor stadigt giver plads til tovtrækkerier, stridigheder eller kampe mellem forskellige interessenter om definitionsretten. Men man kunne også overveje, om begrebets popularitet kan forstås som en samtidsdiagnose. Et tegn på en tendens til et stadigt mere splittet samfund, hvor sammenhænge og samspil reduceres. Under alle omstændigheder giver begrebet "samskabelse" anledning til nye overvejelser over forholdet mellem det personlige og det politiske ansvar for det menneskelige liv. Temaerne her vil blive "Samskabelse" sammen med to andre aktuelle begreber:" Disruptiv Innovation” og ”Det Antropocæne”. De konkrete eksempler vil bl.a. blive Århus kommunes velfærdsstrategi ”Kærlig Kommune” fra 2016, regeringens Disruptionråd nedsat 2016, problemerne med sundhedsplatformen i Region Hovedstaden 2017 samt jobtræningsindsatsen i Københavns Kommune, som har foranlediget konflikten omkring jobcenteret på Lærkevej 2017.11.04.

*) Katrin Hjort er professor ved Institut for Kulturvidenskaber på Syddansk Universitet 


\section{A. Baggrund}

Fredericia Teater har spillet forestillingen "Klokkeren fra Note Dame” i Disney versionen. Forrygende flot og fascinerende. Forestillingen bygger på Victor Hugo's klassiker fra 1831 om Vor Frues Kirke I Paris. Men denne historie ender godt. Den onde kardinal, der styrer både kirke og konge, styrter i 3D ned fra kirkens tårn. Og den smukke og gode sigøjnerpige Esmaralda befrier sammen med den brave soldat Phoebus den deformerede og depraverede - læs fysisk og psykisk udfordrede - Quasimodo, der har været indespærret i tårnet for at skærme ham mod borgerne eller omvendt. "Nogen må jo tage et ansvar", siger Esmaralda, og de tre flygter ud i friheden og fremtiden.

Et af vores dagblade bragte i sommeren 2017 et læserbrev, hvor en læser fortalte om et etisk dilemma, hun havde oplevet. I det lokale supermarked havde hun mødt en tydeligt dement, ældre kvinde med den våde ble hængende ud under kjolen. Læseren havde grebet ind og hjulpet kvinden hjem, men var nu I tvivl. Var det rigtigt at gøre, eller havde hun invaderet et andet menneske. Blandet sig I noget, der ikke kom hende ved? Hvis jeg skulle svare, så ville jeg sige, at det da aldrig kan være forkert at gøre sit bedste for at tage vare på et menneske, som ikke kan tage vare på sig selv. Men jeg ville også undre mig: Nogen må da tage et ansvar. Også vores samfund, hvis ikke vi vil overlade det sårbare liv - vores eget og andres - til tilfældige forbipasserendes nåde og barmhjertighed? Eller med andre ord: Hvordan forhindrer vi, at et menneske reduceres til, hvad Giorgio Agamben (1995) betegner som "det nøgne liv"- et umyndigt og umælende væsen uden borgerens ret til statens beskyttelse. ${ }^{\mathrm{i}}$

Næstekærlighed eller barmhjertighed er centralt i alle de tre store monoteistiske religioner Jødedom, Kristendom og Islam. Som bekendt har det ikke forhindret forfærdende grusomheder i Guds navn. Fordringen om næstekærlighed har også givet anledning strid om, hvem "næsten” er: Er det den, der står uden for vores dør, vores familie, venner, slægt, landsmænd? Eller er fordringen universel? Omfatter alle, også de fremmede og vores fjender? ${ }^{\mathrm{ii}}$

I forbindelse med Lutheråret 2017 er der blevet ført en debat mellem bl.a. professor Jørn Henrik Petersen, Syddansk Universitet og professor Frederik Stjernfeldt fra Aalborg Universitet. Jørn Henrik Petersen, der har været økonomisk vismand, argumenterer for, at (sekulært-) religiøse referencerammer - navnlig den evangelisk-lutherske kristendom - har haft væsentlig betydning for opbygningen af de danske velfærdsstat. Mens Stjernfeldt med sin baggrund i bl.a. 
videnskabsteori og semiotik påpeger Martins Luthers forankring i autoritære og antisemitiske tankeformer, der på ingen måde harmonerer med et moderne liberalt demokrati. Debatten er ikke afgjort, men det udelukker ikke, at vi (gen-) overvejer spørgsmålet om forholdet mellem det personlige og politiske ansvar for hinanden. Ikke mindst set i lyset af de væsentlige aktuelle og potentielle forandringer af den klassiske nordiske, universalistiske velfærdsstatsmodel, den globale migration og den teknologiske udvikling.

Her bliver begrebet samskabelse relevant. Et begreb, der- som jeg vil vende tilbage til - kan kobles til konceptet” Disruptiv Innovation”. Samskabelse kan også ses som en udfoldning af New Public Governance, NPG, der er tænkt som det nye styringsparadigme, der skal afløse New Public Management, NPM, neoliberalismen eller ”Den tredje Vej. Men samskabelsesbegrebet kan også ses som en forlængelse af neoliberalisme og konkurrencestatskonstruktion og i relation til de ordoliberale eller socialstatslige strømninger i Europæisk politik, især i Tyskland. Eksemplerne bliver Århus kommunes velfærdsstrategi "Kærlig Kommune” fra 2016, regeringens Disruptionråd nedsat 2016, problemerne med sundhedsplatformen i Region Hovedstaden $2017 \mathrm{og}$ jobtræningsindsatsen i Københavns Kommune, som bl.a. har foranlediget demonstrationerne omkring jobcenteret på Lærkevej i 2017.

\section{B. Nogle centrale begreber}

Begrebet "samskabelse" - "co-creation" eller "co-production" er oprindelig et begreb for innovation, f.eks. i form af produktudvikling, der sker i samarbejde mellem virksomheder og kunder. Samskabelsen kan have form af feedback fra brugerpaneler, der afprøver nye produkter eller procedurer. Mere avanceret kan det være interaktive processer, hvor brugerne spiller ind med nye behov og ideer via personligt fremmøde eller mindre omkostningstungt via net, hvor deres færden på hjemmesiderne samtidig kan følges. Den nye teknologi gør det i dag også muligt at målrette reklamer - ikke kun til specifikke kundesegmenter - men til specifikke individer, som det f.eks. kan opleves i lufthavnene, når de store reklameskærme lige pludselig reklamerer for bestemte varer på baggrund af, hvilke stande, man har standset ved på vej gennem Tax Free. iii

Når vi kommer til velfærdsarbejdet med sundhed, uddannelse og social sikring, så henviser samskabelsesbegrebet imidlertid til en radikal omtænkning eller omvending af den klassiske nordiske velfærdsstatsmodel, hvor ambitionen var "at give alt det bedste til alle" (Briggs 1961). Gennem samvirke mellem alle gode kræfter i den offentlige sektor, private virksomheder og fonde, 
civilsamfundets frivillige organisationer og privatpersoner er det håbet at kunne skabe - ikke en velfærdsstat - men et velfardssamfund, der bygger på hjalp til selvhjalp. Det enkelte menneske antages grundlæggende ikke at ville være afhængigt af andre - og slet ikke af offentlig forsørgelse - men vil kunne klare sig selv. Idealet bliver ”Den kompetente klient”, der selv har ressourcer til at handle og træffe beslutninger. Men der installeres samtidig en ny skelnen mellem ydere og nydere, rettigheder og pligter. Det bliver en pligt for alle at yde, mens (minimale) rettigheder tilkendes dem, der ikke gør en tilstrækkelig indsats for at blive selvhjulpne. Her anes den skelnen mellem værdigt og ikke-værdigt trængende, der ellers blev afskaffet i Danmark med K.K. Steinckes socialreform efter Kanslergadeforliget i 1933.

Med samskabelsesmodellen vendes velfærdsmodellen så at sige på hovedet. Det afgørende ansvar for borgernes velfærd flyttes fra det offentlige, stat og kommuner til familie, (lokale) sociale netværk, frivillige organisationer, private virksomheder og fonde. Princippet er derfor som udgangspunkt selekterende. Borgernes adgang til velfærd og velvære bliver på nye og afgørende måder afhængig af private relationer og privatøkonomi, herunder private forsikringer (Hjort, 2015).

Ledelsesmæssigt lægger modellen op til, at den offentlige mål- og resultatstyring suppleres med distribueret ledelse - ledelses i teams, hvor medarbejderne selv prioriterer og fordeler arbejdsopgaver og ressourcer, herunder tid. Der skal ikke være en fast tilknytning mellem bestemte professionelle og deres klienter - ingen "livslange relationer", som Kærlig Kommune formulerer det. Borgerne skal kunne henvende sig pr. telefon og mail til teamkoordinatorer, der rådgiver, men kun i nødstilfælde sendes en medarbejder til borgerens bolig.

Velfærdsteknologi som selvfungerende toiletter og badefaciliteter, robotstøvsugere, handicap-elkøretøjer og sågar robotkæledyr kan bidrage til selvhjulpenheden. I stedet for hjælp i hjemmet fra social- og sundhedsmedarbejdere er hensigten, at borgerne selv skal henvende sig til andre instanser. F.eks. henvende sig på apoteket for at få hjælp til at tælle medicin op. Til biblioteket for at få hjælp til benytte ny informationsteknologi. Eller til frivillige ”spise-venner”, hvis selskab kan bidrage til, at de får spist og drukket, så de ikke dehydrerer.

Elektroniske kald kan udgøre en sikkerhed i tilfælde af f.eks. faldulykker. Der findes også apps, hvorigennem privatpersoner kan få oplyst hinandens placering, hvis de ikke svarer på en 
opringning f.eks. inden for 20 minutter. Det er i dag almindelig praksis, at taxachauffører, der oplever, at deres kunder er alvorligt konfuse eller mentalt ustabile, gennem taxacentralen henvender sig til politiet, der undersøger, hvor vedkommende skal bringes hen, f.eks. psykiatrisk skadestue. Men Kærlig Kommune foreslår, at også buschaufførerne inddrages i denne type overvågning. De kender jo deres passagerer og kan se, når noget er helt galt.

For de pårørende - familien til fysisk og psykisk udfordrede, uanset alder - kan disse nye principper for velfærd udgøre en stor belastning. De tider, hvor de syge og gamle på godt og ondt boede på aftægt hos familierne, er som bekendt forbi. I dag, hvor såvel kvinder som mænd er på arbejdsmarkedet, og hvor de færreste bliver boende, hvor de blev født, er det ikke alle, der kan tage fri fra arbejde og køre måske flere hundrede kilometer for at tage sig af deres gamle mor eller svigermor, som en sygetransport har sat af i hjemmet.

En undersøgelse fra ældresagen peger på, at især "sandwich-generationen”, der både har børn og børnebørn og ældre eller syge forældre, føler sig pressede. De angiver, at de gerne vil tage sig af alle, også den ældre generation, men det kan være yderst vanskeligt for dem (Ældresagen 2017): En spørgeskemaundersøgelse til samtlige top og mellemleder i gymnasiet har peget på, at især kvinder føler sig nødsaget til at opgive at forfølge en lederkarriere pga. forpligtelser ift. den ældre generation. De efterlyser ikke gode "børnehaver", men trygge "ældrehaver" (Abrahamsen \& Hjort 2007).

”Den omvendte velfærdsmodel” forsøger alt i alt at revitalisere (fantaserede) forestillinger om menneskeligt fællesskab præget af nærhed, velvilje og gensidig omsorg. Men som vi ved fra litteraturen - Agathe Christies romaner kunne være det eksemplariske eksempel - så har disse lokale fællesskaber også være plaget af snagen, sladder og afstandstagen. At ville erstatte velfærdsstaten pligter over for borgerne med borgernes pligter overfor naboen kan derfor uanset hvor sympatisk, det lyder - føre til vantrivsel og vanrøgt.

\section{Disruptiv innovation som begreb}

Når vi kommer til begrebet "Disruptiv Innovation”, som samskabelsesbegrebet ofte kobles med, fortsætter flertydighederne. "Disruption”- den idé, at man ved at lukke ned for alle sædvanlige praksisser og procedurer, kan skabe rum for nye og kreative processer - optræder både som et begreb til økonomisk analyse, som politisk strategi og som arbejdsmarkeds- og uddannelsespolitisk 
prognose. Men gennemgående er den nye teknologi, der både kan optræde som forbandelse og forjættelse.

Begrebet "Disruptive Innovation” introduceres første gang som økonomisk model i USA 2000 af Clayton M. Christensen og hans samarbejdspartnere (Christensen et al. 2000, Christensen 2007). Formålet er at skabe en ny forretningsmodel, der vil kunne bruges både i sundhedsvæsnet, som jo i stort omfang er privatiseret i USA, og i det øvrige erhvervsliv. Teoretisk-analytisk skelnes mellem på den ene side mere "stilfærdige" former for innovation som udvikling af eksisterende eller ny teknologi, og på den anden side den disruptive innovation, der radikalt og ofte uventet udraderer grundlaget for en given produktion. Det populære eksempel på en "stille innovation” er udviklingen af benzinmotoren. Benzinmotoren fik ikke i sig selv den store økonomiske betydning, fordi markedet for luksusbiler var meget lille. Udviklingen af Ford T., som mange kunne have råd til, og som derfor kunne erstatte de hestetrukne vogne, var til gengæld en disruptiv innovation, der fik afgørende og uforudsete samfundsmæssige konsekvenser, både materielt og immaterielt. Internettets overgang fra et militært til et civilt kommunikationsredskab har som bekendt på tilsvarende vis afgørende forandret betingelserne for alle former for lokal, national og global handel.

Man kan sige, at den destruktion af de tyske byer og produktionsanlæg, som de allieredes bombninger af Tyskland ved 2. verdenskrigs slutning medførte, også var et eksempel på innovativ disruption. Ødelæggelsen var - sammen med Marshall hjælpen - en central forudsætning for det tyske Wirtschaftswunder. Men som eksplicit politisk strategi manifesterer disruptiv-tænkningen sig først for alvor i forbindelse med den katastrofe, som orkanen Katharina skabte i byen, New Orleans i 2005. Som beskrevet bl.a. af Noami Klein (2007) blev oversvømmelserne og de deraf følgende ødelæggelser af New Orleans brugt som lokalpolitisk anledning til at renovere byen materielt og menneskeligt. Reparation og genhusning for den fattigste del af borgerne blev ikke prioriteret. Til gengæld blev udlejningsejendomme revet ned, skoler og hospitaler nedlagt eller privatiseret, og der blev satset på boligkvarterer, der kunne tiltrække nye og bedre skatteborgere og turister til jazz-byen. En social selektion, der ikke kun blev økonomisk, men også kulturel, sproglig og etnificeret.

Denne konklusion bekræftes af Richardt Florida, der med bogen "The Rise of the Creative Class " (2002) argumenterede for, at de liberale, kreative og multikulturelle/liberale samfund havde et 
meget større økonomisk vækstpotentiale, end f.eks. de mere konservative stater i Midtvesten i USA. I sin seneste bog "The New Urban Crisis" (2017) peger han med beklagelse på, at der i tiden efter den økonomiske krise i 2008 er etableret en ny form for "gentrificering" eller ulighed i de urbane områder. De veluddannede og velstillede bor i de eksklusive, ofte lukkede og bevogtede områder. Mens det prækariat, som Guy Standing (2011) benævner det, der er afhængige at løst lønarbejde eller sociale ydelser, nødsages til at bosætte sig i yderområder med dårlige transport og uddannelsesmuligheder.

I Danmark er antallet af "Free-lancere” og ”solo-selvstændige” steget de sidste årtier. Antallet af marginalt deltidsansatte er steget fra ca. $6 \%$ i 2001 til ca. 10 \% i 2015 (S. Baltzer 2017). Især blandt akademikere er de midlertidige, frivillige eller ufrivillige projektansættelser stadig mere udbredte. Ca. $25 \%$ af akademikerne er ikke i faste stillinger, mens det kun gælder $10-12 \%$ af den samlede arbejdsstyrke (E.P. Rasmusen 2016). Til gengæld er arbejdsløsheden blandt akademikere ikke større end arbejdsløsheden generelt. Der er således ikke belæg for at hævde, at de er fejl- eller overuddannede. Men det går langsommere for akademikerne at få fodfæste på arbejdsmarkedet ofte 1 til 2 år - og en stor gruppe bliver som nævnt projektansatte (K. B. Rasmussen 2017). Alt i alt ser det ud til, at for første gang i 200 år bliver børn - selvom de er mere veluddannede generelt fattigere, end deres forældre (F.M. Juel 2017 a b).

De aktuelle danske eksempler på (forsøg på) at bruge konceptet disruptiv innovation til arbejdsmarkeds- og uddannelsespolitisk prognose er mindre spektakulære. OECD i estimerede i 2016, at $8 \%$ af den danske arbejdsstyrke er i højrisiko for at miste deres job, fordi deres arbejde automatiseres (Coyle 2016). Samme år nedsatte statsminister Lars Løkke Rasmussen (V) et "Disruptionråd", der skal analysere, hvordan globalisering, automatisering og robottisering vil påvirke fremtidens arbejdsmarked. Etableringen af rådet blev bakket op af LO's forkvinde Lizette Risgaard og Bente Sorgenfrey, forkvinde for FTF. De faglige repræsentanter refererede i den sammenhæng bl.a. til Sirikommissionen, der er nedsat af Ingeniørforeningen i Danmark, IDA og repræsentanter for Radikale Venstre, bl.a. Ida Auken. Sirikommissionen understreger behovet for efter-/videreuddannelse og etisk refleksion i forhold til den digitale revolution (Sirikommisionen 2016).

I forlængelse af Disruptionrådets mandat fremskriver Undervisningsministeriet i 2017 i en profilmodel, hvor mange 9. klasseelever fra fødselsårgangene 1990 til 2015, der vil tage hvilke 
uddannelser: Antallet af unge, der ønsker en gymnasial uddannelse efterfulgt af en mellemlang videregående uddannelse (bachelor) vil være konstant stigende, mens tilgangen til erhvervsuddannelserne vil falde. Fremtidsudsigter, der har ført til uddannelsespolitiske forsøg på at styrke erhvervsuddannelsernes status via strammere adgangskrav, men som (endnu) ikke har haft held med at udvikle en styringsmodel, der kan sikre de nødvendige lærepladser (Skov 2016).

Til gengæld har de to autonome fremtidsforskere, entreprenørerne Anders Hvid og Jannick B. Petersen, Dare Disrupt i bogen "Forstå fremtiden” forudsagt de 6 roller på fremtidens arbejdsmarked: Coder (programmøren), Maker (byggeren), Carer (de varme hænder), Artist (kunstneren), Facilitator (lederen) og Entreprenøren (skaberen) (A. Hvid \& J.B. Petersen 2014). Mens Dansk Røde Kors Ungdom ikke har nøjedes med at spå om fremtiden. De har haft modet til at prøve at skabe den. I tre måneder i begyndelsen af 2017 lukkede de ned for alle sædvanlige aktiviteter (møder, mails, telefoner mv.) og rejste i stedt rundt i landet og talte med 1500 unge for at få nye input og samarbejdspartnere til deres arbejde. ”Det er pisse, fucking svært”, udtaler forkvinden Amalie Utzon ifølge Altinget.dk. (L.C. Lindegaard 2007).

Gennemgående i diskursen omkring ”innovativ disruption” er imidlertid - som nævnt spørgsmålet om ny teknologi (IT, sociale medier, registrerings- og registersamkøringsmuligheder, humanteknologi, genteknologi osv.). Den ny teknologi optræder både som forjattelse og forbandelse. På den ene side er det den ny teknologi, der stiller os nye muligheder i udsigt. På den anden side er det den nye teknologi, der er årsagen til, at vores velfærdssamfund vakler eller går til grunde, hvis vi ikke forstærker brugen af den ny teknologi. Nogle eksempler kunne være sagen om Region Hovedstadens nye sundhedsplatform, der er blevet stærkt kritiseret som ubrugelig eller direkte kontra-produktiv i forhold til såvel patientbehandling som med hensyn til praktisk og økonomisk effektivitet. Her kunne man, hvis man tog samskabelsestanken alvorligt, sige, at det er fraværet af samskabelse, der har skabt problemet. Mangel på input og feedback fra de direkte og indirekte brugere (professionelle fagpersoner og patient-organisationer), mangel på viden om hvor kompleks udvikling og implementering af så store IT-systemer er, og mangel på hensyn til den lokale/nationale kontekst, kulturelt og økonomisk (H. Drachmann \& A.L. Schmidt 2017).

Omvendt kan de nye eksempler på hacking via de globale digitale netværk (virus orme, trojanske heste, ransomware) antages at være resultater af eksemplarisk samskabelse, netværksdannelse og innovativ disruption. Det kan f.eks. ikke udelukkes, at virussen, WannaCry, der i maj 2017 
lukkede IT-systemerne på omkring 100 hospitaler i hele verdenen efterfulgt af krav om løsepenge i bitcoins for at åbne dem igen, er udviklet i netværkskredse, der beskæftiger sig såvel med udvikling af virus som med sikkerhedssystemer mod virus (Hannestad 2017).

Så innovativ disruption kan tænkes og gøres på mange måder. Det er stadig en flydende betegner, der kan slås om, og det er muligvis også heri, begrebets potentialer ligger (Barkholt 2017).

\section{Den tredje vej?}

Samskabelse kan som nævnt forstås som en udmøntning af tankerne om New Public Governance, der skulle være det nye styringsparadigme, der skal afløse New Public Management som offentlig styringsstrategi. Karakteristisk er fokus på samarbejde på tværs af offentligt og privat gennem netværk, partnerskaber, virtuel kommunikation og nye former for udveksling af goder af materiel og immateriel art (Osborn 2009, Thorfing et al. 2010).

Men begreberne samskabelse og disruption forbinder sig imidlertid også til den neo-liberale politik, som Anthony Giddens (1998) har benævnt ”Den tredje vej”, og som er forsøgt implementeret af Tony Blair's ”New Labor" og Bill Clinton's ”New Democrats”. I Danmark er den blevet repræsenteret af statsminister Helle Thorning-Schmidt (2011-2015) (Herlev Lund 2005). Her forlades de keynesianiske bestræbelser på at afbalancere de konjunktursvingninger og sociale uligheder, som markedet skaber. Statens opgave bliver at iværksætte foranstaltninger, der kan støtte markedet, herunder nationers, regioners, virksomheders og individers konkurrencedygtighed på et globalt marked. Den foretrukne styringsstrategi bliver New Public Management, mål og kontraktstyring, og ambitionen om at stræbe mod "reel lighed" erstattes af ønsket om "chance lighed", dvs. at alle - uanset baggrund, køn, hudfarve osv. - skal have lige stor statistisk sandsynlighed for social opstigning. Men samtidigt konstrueres nye offentlige diskurser, der skelner mellem "vindere og tabere", ”ydere og "nydere", ”rettigheder og pligter". Men pligter og byrder skal ikke længere - som i den klassiske socialdemokratiske retorik - hvile på de bredeste skuldre, men i særlig grad pålægges de tabere, der antages at nyde uden at yde.

Den neoliberale konkurrencestatstænkning og NPM konkurrerer imidlertid - især i europæisk regi - med den ordoliberale statstænkning, som bl.a. den tyske forbundskansler Angela Merkel ses som repræsentant for, men som allerede Konrad Adenauer og Ludwig Erhardt stod for. Begrebet ordoliberalisme blev introduceret i 1950 og henviser til en række klassisk liberale fra den såkaldte 
Freiburg School, der etablerede sig i Tyskland mellem 1930 og 1950 (Walter Eucken 1891-1950, Franz Böhm 1895-1977, Leonhard Miksch 1901-1950) Friedrick 1995, Massimiliano 2010, Megay 2010).

De ordoliberale idealer er at skabe en "Social Markeds Økonomi”, og de formulerer sig i opposition ikke kun til kommunisme og nazisme, men også til keynesianisme og neoliberalisme. For de ordoliberale handler det hverken om at eliminere, regulere eller facilitere markedet, men om at konstruere markedet. Intentionen er at konstruere et fair marked ved at afværge markedets uønskede konsekvenser: Centralisering af kapital i form af monopoldannelse og oligarki. Redskaberne er først og fremmest: Fast monetar politik styret af uafhængige centralbanker (fastkurspolitik) med henblik på at forhindre inflation og valutaspekulation samt styrke betalingsbalancen. Stram finanspolitik, der nøje balancerer offentlige udgifter og indtægter, undgår eller afvikler offentlig gældsætning og modarbejder inflation. Uafhæengige domstole, der arbejder på et juridisk grundlag af politisk fastsat markedslovgivning, f.eks. om markedsføring, kvalitetsstandarder, deklarationer mv. Vitale ressourcer som telekommunikation skal være i statens hænder, skatteniveauet skal holdes moderat, men må godt være progressivt, og der er ikke modvilje mod et vist niveau af sociale ydelser. Heraf navnet Den Sociale Markedsstat eller Socialstaten. Spørgsmålet om borgernes nationale tilhørsforhold er mindre interessant. Det overlades til udbud og efterspørgsel i den sociale markedsøkonomi.

Kronen har som bekendt været bundet til euroen i det europæiske valutasamarbejde ERM2 siden 1999, dvs. Danmark er med i et fastkurssamarbejde, der til en vis grad har begrænset mulighederne for en ekspansiv finanspolitik. Men siden årtusindskiftet har det foretrukne politiske valg - trods regeringernes skiftende partifarver, dvs. på tværs af de traditionelle venstrehøjre skel og ofte på tværs af partiernes indre linjer - også været reduktion af de offentlige udgifter til velfærd: sundhed, uddannelse og social sikring samt skattelettelser, der har favoriseret skatteborgere med de højeste ind tægter (Olsen 2014, CEVEA 2017).

\section{E. Konkurrerende statsmodeller}

Det ville imidlertid være forenklet at hævde, at der i Danmark i dag kun er én statsmodel, der dominerer den politiske arena. Det ville været mere præcist at beskrive den aktuelle statsmodel som en konglomeratstat, hvor forskellige statsmodeller konkurrerer om at sætte den politiske dagsorden: 


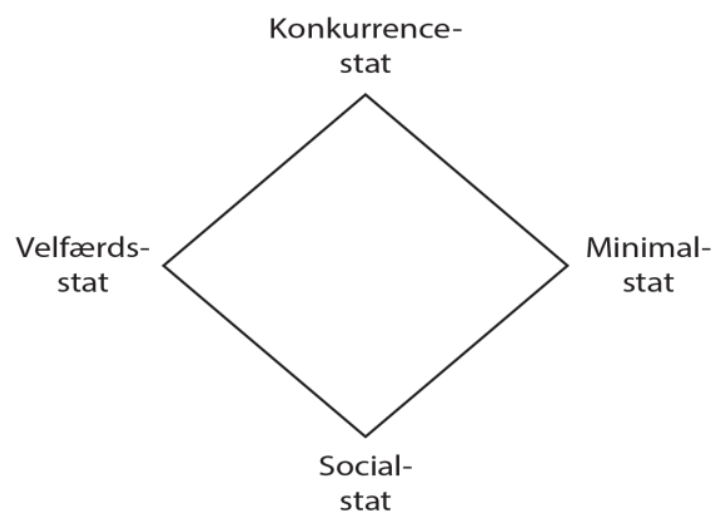

Figur 1: Konkurrerende statsmodeller

Dette særegne mix kan få særprægede konsekvenser for borgerne: På den ene side formuleres velfærdsstatsideologien stadigt - alle skal med i fællesskabet/alle skal blive så dygtige, som de kan. På den anden side vendes velfærdsmodellen som beskrevet om: Gennem samskabelse skal det offentlige, stat og kommune i samspil med private aktører og borgerne selv udvikle hjælp til selvhjælp i et meningsfyldt samvær, der styrker alle parters konkurrencedygtighed. Men hermed installeres også troen på, at menneskers motivation udspringer af egennytten, herunder stræben efter flest mulige penge for mindst muligt arbejde. Et synspunkt, der berettiger den stramme ordoliberale finanspolitik og nedskæringerne på de offentlige budgetter. For det skal jo kunne betale sig at arbejde. Så borgere, der har brug for hjælp, risikerer at blive fanget i et catch 22 eller en dobbelt-bind-situation, hvor det ikke hjælper, lige meget hvad de gør. Demonstrationerne på Lærkevej er et eksempel.

\section{F. Lærkevej som eksempel}

28. oktober 2017 blev der afholdt en demonstration foran Københavns Kommunes jobcenter på Lærkevej 18 i Nordvest Kvarteret. Initiativtagerne var bevægelserne ”Jobcenterets ofre” og "Næstehjælperne”, og deltagerne var borgere, der selv var involveret i de såkaldte ressourceforløb, arbejdsprøvning eller jobtræning, samt en lang række sympatisører. Anledning var et "sengemøde". En kvinde, der var så syg bl.a. af en hjernesvulst, at hun måtte ligge i sin seng under mødet, var blevet indkaldt af jobcenteret. Hun var blevet nægtet førtidspension, men skulle i stedet igennem flere arbejdsprøvninger. I forbindelse med demonstrationen - og en række tilsvarende andre steder i Danmark - kom en række "uintenderede eller uønskede" konsekvenser af reformen frem i pressen: Ineffektivitet, dødelighed, nye former for børnefattigdom knyttet til 
den aktuelle kontanthjelpsreform, 225 timers kravet og integrationsydelsen. Hertil kommer overbelastning af sagsbehandlerne.

Førtidspensionen blev reformeret i 2012 støttet af alle partier minus Enhedslisten. Hensigten var at bringe de ledige nærmere arbejdsmarkedet. Ingen under 40 skal som udgangspunkt have førtidspension, men for alle gælder, at hvis sygedagpenge ikke - på baggrund af de kommunalt lønnede lægekonsulenters udtalelser - kan forlænges, så tilbydes i stedet ressourceforløb eller afklaringsforløb i form af arbejdsprøvning, ulønnet virksomhedspraktik, ansættelse med løntilskud til virksomheden eller jobtræning hos anden aktør (virksomheder, der for kommunen foretager arbejdsprøvning og arbejdstræning). Hensigten er at sikre, at al resterende arbejdsevne - aktuel eller potentiel - er udnyttet. Under jobafklaring udbetales ressourceforløbsydelse til borgeren, eller hvis praktikken er lønnet, til arbejdsgiveren.

Reformen af førtidspensionen indgår i en kæde af reformer af den sociale bistand i Danmark:

Kontanthælpen blev reformeret i 1994, 1996 og 1998 med en række foranstaltninger, der skulle aktivere de ledige gennem jobtræning eller uddannelse, herunder alle under 30 år. Imellem 2004 og 2014 bølger spørgsmålet om kontanthjalpsloft, dvs. loft over de samlede sociale ydelser; kontanthjælp, boligtillæg og boligsikring, frem og tilbage. Men med kontanthjælpsloftet i 2014 og indførelsen af 225 timers reglen medregnes ægtefælles/samlevers indtægt, og begge parter skal opfylde et arbejdskrav på 225 timer ustøttet arbejde. Hvis ikke, nedsættes kontanthjælpen eller falder helt bort. Integrationsydelsen blev vedtaget af Venstre, Dansk Folkeparti, Liberal Alliance og De konservative i 2015 med det formål at gøre det "mindre attraktivt at komme til Danmark og mere attraktivt at arbejde og bidrage til de danske samfund". Integrationsydelsen betyder bl.a., at par med børn får ca. 12.000 mindre udbetalt om måneden. Hvis man har bestået danskprøve 2 kan man opnå et tillæg på 1500.kr. (Beskæftigelsesministeriet 2015).

Samlet har disse reformer imidlertid - som sagen omkring Lærkevej har demonstreret - kunnet få en række uhensigtsmæssige eller direkte kontra-produktive konsekvenser.

Ineffektivitet: Ressourceforløbene er tilsyneladende ikke særligt effektive set i forhold til målsætningen om arbejdsmarkedstilknytning. I perioden 2013-2016 har knap 30.000 personer været i ressourceforløb, heraf er ca. 10.000 afsluttede. 81 personer, dvs. $2 \%$ af de afsluttede er 
kommet i beskæftigelse. 774 personer, dvs. 8\% er kommet i fleksjob, og 84 personer dvs. 1\% er begyndt en uddannelse (Nørup 2017). En undersøgelse blandt 95 af landets 98 kommuner foretaget af nordjyske .dk viser, at over 200 borgere havde forladt ressourceforløbet uden at få et job, dvs. var blevet såkaldt”selvforsørgende” uden fast indtægt (C. Birk \& L. Tellmann 2016) .

Dødelighed: Undersøgelsen fra nordjyske.dk viser også, at mindst 65 borgere er døde, mens de var i ressourceforløb (C. Birk \& L. Tellmann 2016). Undersøgelsen hævder $i k k e$, at ressourceforløbene var den kausale årsag til, at disse mennesker døde. Under alle omstændigheder ville de muligvis have være døde af den sygdom, de led af. Men undersøgelsen peger på, at en række - dødeligt syge - borgere har været sat i ressourceforløb. Flere psykiatere samt professor i jura Kirsten Ketcher, Københavns Universitet har udtalt, at ressourceforløbene direkte har forværret de berørtes helbred, eksempelvis blandt patienter med diagnoser som skizofreni eller bi-polære lidelser (K. Ketcher 2016).

Ny børnefattigdom: 62.073 børn er de sidste 3 måneder i 2016 blevet berørt af deres forældres nedsatte indkomst på grund af kontanthjælpsloftet, 225 timers reglen og integrationsydelsen, oplyser et svar til Folketinget fra beskæftigelsesminister Troels Lund Poulsen, Venstre ifølge Danmarks Radio 20. marts 2017. Forældrene har vanskeligt ved at skaffe basale fornødenheder som vintertøj, støvler og sund mad, og vanskeligheder ved at have råd til børnefødselsdage og kontingent til fritidsaktiviteter. En række frivillige organisationer, bl.a. Red Barnet har derfor taget initiativ til samskabelse i form af indsamling af tøj, og en børnehave i Kolding måtte i 2016 starte en tøjindsamling blandt forældrene for at kunne give til de forældre, der ikke havde råd (Christensen 2016).

Til denne række af uhensigtsmæssigheder kommer overbelastning af sagsbehandlerne. SL, Socialrådgivernes Landsforening har oplyst, at de sagsbehandlere på Lærkevej, der har ansvar i forhold til "aktivitetsparate borgere" i gennemsnit, har ansvar for 220 sager. Det er det højeste tal i landet og langt over det anbefalede. Sagsbehandlerne på Lærkevej har selv i et læserbrev beskrevet, hvordan arbejdspres forhindrer dem at gøre deres arbejde ordentligt (Christoffersen 2017, Langhoff et al. 2017). En sådan overbelastning disponerer ikke bare som overarbejde og overbelastning i traditionel forstand for stress og øget sygelighed. Mennesker, der arbejder med mennesker i professioner med høje etiske idealer og samfundsmæssige opdrag, er særligt udsatte. Fænomenet benævnes Etisk Press - Moralsk Stress (Bræmer 2015, Ribers 2017). 


\section{G. Ud eller ind i det gode liv?}

Hvis vi spoler tilbage til "Klokkeren fra Notre Dame”, så demonstrerede borgerne i Paris' gader mod magthaverne, mens den indsatte, Quasimodo flygtede $u d$ i det gode liv. På Lærkevej demonstrerede borgerne for, at de udsatte kunne komme ind til et bedre liv. Striden i velfærd i dag handler om adgang til de arenaer, hvor der kan ydes god fysisk, psykisk og social omsorg. Det gælder ikke kun mennesker, der udsætter sig for at drukne i Middelhavet eller Den Mexicanske Golf i søgen efter livet eller lykken. Striden handler også om mennesker, der allerede er bosatte i det tilsyneladende privilegerede Danmark (Gilles Deleuze 2005, Hjort 2013).

De periode, vi befinder os i dag, kan beskrives som antropocan. Den posthumane vending betyder, at mennesket i den antropocentriske periode har forbundet sig med alt dødt og levende materiale i en grad, at det er blevet i stand til at destruere sit eget eksistensgrundlag, som Nobelpristageren i kemi år 2000 Paul J. Crutzen formulerede det i 1986.

Vi handler ofte - ikke af uvidenhed - men mod bedre vidende. Men det betyder ikke, at vi nødvendigvis skal valge at bidrage aktivt til vores egen og klodens ødelæggelse. Det gælder med hensyn til atomoprustning og krigstrusler og med hensyn til det, der i visse kredse kaldes "usædvanlige vejrfænomener”. Men det gælder også i hverdagen.

Så selvfølgelig skal vi bestræbe os på at behandle også dem, vi ville betragte som fremmede eller fjender, med barmhjertighed og næstekærlighed. Nogen må jo tage et ansvar-også for at skabe noget sammen. 


\section{Referencer}

Abrahamsen, M. \& K. Hjort. Baglans på Høje Hale. Odense: Gymnasiepædagogik 106, 2017.

Agamben, G. Homo Sacer. Århus: Klim, [1995] 2016.

ArbejderbevægelsensErhversråd. Fattigdom trakker spor ind $i$ voksenlivet. København:

Arbejderbevægelsens Erhvervsråd, 2017.

Baltzer, S. Flere bliver løstansatte: Anna har sagt farvel til 8 arbejdspladser på fem år. 18.52017. https://www.dr.dk/.../flere-bliver-loestansatte-anna-har-sagt-farvel-til-otte-arbejdsplads

Barkholt, N.C.: Samskabelse - hvordan og hvorfor". https://kommunen.dk/blog/samskabelsehvordan-og hvorfor?

Beskæftigelsesministeriet. Straksindgreb på asylområdet - ny integrationsydelse til nytilkomne udlandinge.

Birk, C \& L. Tellmann. 9. 5 2016. http://nordjyske.dk/nyheder/mindst-65-doede-iressourceforloeb

Bræmer, M: Stress-ekspert: Man skal narmest vare elitesoldat for at vare ansat $i$ det offentlige $i$ dag. http://www.ugebreveta4.dk/man-skal-jo-naermest-vaere-elitesoldat-for-at-vaerea 20297.aspx 1.072015.

Beskæftigelsesministeriet (2015) "Straksindgreb på asylområdet"

http://bm.dk/da/Aktuelt/Pressemeddelelser/Arkiv/2015/07/straksindreb\%paa20asylom raadet $\%$

Boehmer R., J. Kenagy \& C.M. Christensen. »Will Disruptive Innovations Cure Health Care?« Harward Business Press 78 no 5, 2000: 102-117

Briggs, A. The Welfare State in Historical Perspektive. Cambridge: Cambridge University Press, Archives Européennes de Sociologie, 2, 221 pp.221-258.

CEVEA. Ulighedheden stiger mest $i$ Danmark. Videnskabelig rapport, København: CEVEA centrum-venstre tænketanken, 2014.

Christensen, C.M. The innovators solution: creating and sustaining succesful groth. Harward: Harward Business Press, 2003.

Christensen, E. Fattige Børn: Børnehave tigger om tøj. 15. 11 2016. https://newsbreak.dk/fattigeboern/

Christoffersen, E: Der er uendeligt langt fra Rådhuset til Københavns Jobcentre. 16. 102017. https://www.information.dk/debat/2017/10/uendeligt-langt-raadhuset-koebenhavnsjobcentre 
Crutzen, P. J. "Is the Detergent of the Atmosphere Decreasing: Importance of Methane for the Radical Concentration and Atmospheric Photochemistry”. Bruxelles: Europa Kommissionen, 1986.

Deleuze, G. Two Regimes of Madness: Texts and Interviews 1975-1995” . 2015. http://semiotexte.com/

Drachmann, H. \& A.L. Schmidt. Striden om Sundhedsplatformen - Hovedstaden foretrak en amerikansk model frem for en jysk. 3. 9 2017. http://politiken.dk/indland/art6091599/Hovedstadenforetrak-en-amerikansk-model-frem-for-en-jysk

Dyole, D. The Digital Disruption of Productivity. 11. 10 2016. www.org

Florida, F. The Rise of The Creative Class. New York: Basic Books, 2002.

Florida, R. The New Urban Crisis. London: OneWorld, 2017.

Friedrich, C.J. »The Political Thought of Neo-Liberalism.« American Political Science Review 49 (2), 1955: 509-525. https://doi.org/10.2307/1951819

Giddens, A. The Third Way: The Renewal of Social Democracy. Cambridge: Polity, 1998.

Hannestad, A. Vi burde uddanne hackere: Cand.hack. 27. 05 2017. https://www.atea.dk/omatea/presse/nyheder/2017/vi-burde-uddanne-hackere-cand-hack-eller-cand-cybercrime/

Hartlund, B:. »Chokerede flygtninge fryser i teltlejr - vi troede Danmark var et rigt land.« BT, 24. 032015

Herløv Lund, H. »Helle Thorning Schmidt:"New Labour" in Denmark.« http://www/kritiskdebat.dk. 15. October 2005.

Hvid A. \& J. B. Pedersen. Der venter 6 roller på fremtidens arbejdsmarked. 2017. 5 4. www.altinget.dk

Hvid A. \& J.B. Petersen. Forstå fremtiden. København: Peoples Press, 2014.

Juel, F.M. Så grum er dansk vakstkrise: Børn bliver fattigere, end deres foraldre. . 28. 072017. www..business.dk/oekonomi/saa-grum-er-dansk-vaekstkrise-boern-bliver-fattigere-endderes-foraeldre

Juel, J.S. Flere fattige og udsigt til stor stigning. København: Arbejderbevægelsens Erhvervsråd, 2017.

Juul, J. S. Regeringen fordobler antallet affattige børn. København: Arbejderbevægelsens Erhvervsråd, 2016.

Ketcher, K. Borgerne har mistet retten til at vare syge. 30.012016. http://www.altinget.dk/artikel/ 145780-professor-borgerne-har-mistet-retten-til-atvaere-syge

Klein, N. The Shock Doctrine. New York: Metropolitan Books, 2007.

Kølln, T. »Sådan gjorde politikerne Danmark Fattigere.« Magisterblader, 18. August 2017. 
Olsen, L., N. Ploug, L. Andersen, S. E. Sabiers \& J.Goul Andersen. Klassekamp fra oven - den danske samfundsmodel under pres. Købemhavn: Gyldendal, 2014.

Laclau, E. »Why do Empty Signifiers matter to Politis? « I The Lesser Evil and the Greater Good, af Weeks (ed.), 167-178. London: River Gram Press, 1994.

Langhoff, I. et al. Ingen kan hjalpe en udsat ledig til en bedre fremtid på 25 minutter. 18. 092917. https://www.information.dk/debat/2017/o9/ingen-kan-hjaelpe-udsat-ledig-bedrefremtid-paa-25-minutter

Law, J. Actor Network Theory and Material Semiotics. 18. 052007. www.heterogeneties/Law2007ANTandMaterialSemiotics.pdf

Lindegaard, Lærke Cecilie. Ungdommens Røde Kors har disruptet sig selv. 20. 04 2017.

http://www.altinget.dk/artikel/ungdommens-roede-kors-har-disrupted-sig-selv-det-erpisse-fucking-svaert

Lylloff, K. »Kan lægeløftet gradbøjes.« Historisk Tidsskrift, 1999: 33-67.

Massimiliano, V. »The Ordolibeberal notion of market power: an institutionalist reassesment.« European Competition Journal 6 (3), 2010: 689-707. https://doi.org/10.5235/ecj.v6n3.689

Megay, E. N. »Anti-pluralist Liberatism: The German Neoliberals. « Political Science Liberal Quarterly Vol 85 No 3., 2010: 689 707. Nørup, I. Kun Troels Lund Poulsen kan få øje på fortidspensionsreformens vindere. 17. 10 2017. www.information.dk/debat/2017.

Ojakangas M.: »Lutheranism and Nordic Biopolitcs.«RETF ARRD 38 3/159, 2015: 5-23

Olsen, , L. et al. Klassekamp fra oven - den danske samfundsmodel under pres. København: Gyldendal, 2014.

Osborne, S.P.:The New Pubic Governance? London: Routlegde

Pedersen, O.K. Konkurrencestaten. København: Hans Reitzels Forlag, 2011.

Petersen, J. H. Fra Luther til Konkurrencestaten. Odense: Odense Universitetsforlag, 2017.

Pralahad C.K. \&, Vemkat Ramaswamy \& C.K. »Co-opting Customers Competence.« Harward Business Review 78 (1), 2000: 79-87.

Rasmussen, E. »Klimakampens danske taberopskrift.« mandagmorgen. 26. juni 2017. http://www.mm.dk (senest hentet eller vist den 24. juli 2017).

Rasmussen, Elise Patricia. Flere akademikere arbejder som freelancere og projektansatte. 26.102016. https://www.dr.dk/nyheder/regionale/midtvest/flere-akademikere-arbejder-somfreelancere-og-projektansatte

Ribers, B. (2017) "Etiske Cirkler" i A. Kristiansen et al. ed: Etikk i Profesjonsudøvelse, Oslo: Gyldendal 
Hjort / Nogen må jo tage et ansvar

Rasmussen, K. B. »Overuddannelse er en myte.« Forskerforrum, $112017: 2$.

Skou, M. T. : 12.000 unge mangler Larepladser. https://fagbladet3f.dk/artikel 27.2. 2016

Sirikommissionen. Sirikommissionen. København: IDA, 2016.

Standing, G. The Precariat - The New Dangerous Class. London/New York: Bloomsbury Academic, 2011.

Stjernfeldt, F. Syv Myter om Martin Luther. København: Gyldendal, 2017.

Thorfing, J, et al: Interative Governance.Oxford: Oxford University Press

Undervisningsministeriet. Profilmodellen. 10. 3 2017. https://uvm.dk/statistik/tvaergaaende...afen.../profilmodel-definition-og-metode.

Ungdommens Røde Kors har disruptet sig selv. u.d. http://www.altinget.dk/artikel/ungdommensroede-kors-har-disrupted-sig-selv-det-er-pisse-fucking-svaert.

Ældresagen. Undersøgelse af pårørende $i$ Danmark. 07 2017. www.aeldresagen.dk

\begin{abstract}
i Giorgio Agamben's grundeksempel er Holocaust, men af nyere eksempler kan nævnes lejrene for tyske flygtningen i Danmark efter 2. verdenskrig, hvor Danmarks Lægeforening forbød sine medlemmer at praktisere, hvad nogle af dem gjorde alligevel (Lylloff 1999). Samt de desværre lidt for aktuelle sager omkring standarden i de danske asylcentre efter den såkaldte flygtningekrise satte ind, dvs. efterhånden som antallet af flygtninge og asylansøgere steg i forlængelse af de eskalerende krigshandlinger i

Mellemøsten (B. Hartlund 2015).
\end{abstract}

ii Toraen en: "Du skal elske din næste som dig selv" (3. Mosebog 19 vers 18) "Den fremmede, der bor som gæst hos jer, skal være som en af landets egne, og du skal elske ham som dig selv" (3. Mosebog 19 vers 33 ). Biblen. Det nye Testamente: "Som jeg har elsket jer, skal I også elske hinanden" (Johannes 13 vers 34). "Elsk jeres fjender, gør godt og lån ud uden at håbe på at få noget igen" (Lukas 6 vers 37).

Koranen:"I skal være gode imod jeres forældre og slægtninge, forældreløse og fattige" (Koranen, Sura 04 vers 036). "Lad der af jer blive ét fællesskab, der kalder til det gode, påbyder det rette og forbyder det forkastelige! Dem vil det gå godt" (Koranen, Sura 3 vers 104). Et af Allahs 99 smukke navne er "Den Barmhjertige" og regler for anvendelse af almissen (Zakat) omtales såvel i Koranen, der læses af alle muslimer, som i de Hadither, der kun læses af sunni-muslimer.

iii I dag er det også teknisk muligt via de såkaldte "kardiografiske analyser", der kortlægger kontakter og relationer på nettet, med stor sandsynlighed at forudsige, hvem der befinder sig hvor, og hvilke handlinger, de potentielt kan foretage sig. (BIG DATA) Den kardiografiske metode er udviklet i tilknytning til den "Aktør-Netværks-Analyse", som bl.a. Bruno Latour har stået i spidsen for, og som i princippet kan bidrage til fænomenet "Preventive Policing", dvs. forudsige sandsynligheden for, hvilke personer der vil foretage kriminelle handlinger, hvor og hvornår (John Law 2007). 